\title{
Adoption of conservation agriculture practice in Bangladesh: Impact on crop profitability and productivity
}

\author{
M. T. Uddin*, A. R. Dhar and M. M. Islam \\ Department of Agricultural Economics, Bangladesh Agricultural University, Mymensingh-2202, Bangladesh \\ *Email: tajbau@yahoo.com
}

\begin{abstract}
The study was conducted to assess the impact of conservation agriculture practice on crop profitability in Bangladesh and to identify the determinants of adopting such practice. A total of 300 farmers (50 focal, 100 proximal and 150 control) from five districts (Mymensingh, Bogra, Tangail, Sherpur and Jamalpur) were selected. Focal farmers were selected purposively; and proximal and control farmers were selected randomly. Descriptive statistics like sum, averages, percentages and ratios were calculated to evaluate the socioeconomic data. Profitability of crop production was measured in terms of gross return, gross margin, net return and benefit cost ratio (BCR). Crop productivity was measured using the Enyedi's crop productivity index. The BCR of focal, proximal and control farmers were $2.58,2.24$ and 2.18, respectively. The crop productivity of focal, proximal and control farmers were increased by $0.5,1.1$ and 1.4 percent, respectively with respect to the entire region. Educational level of household head, farm size, farm income, extension contact and farming experience were found as significant factors through logit model that affect the adoption of this practice by the farmers. Input support, motivation, training programmes and extension services by different government and non-government organizations should be properly organized and implemented to raise the consciousness and enhance the knowledge of the farmers on conservation agriculture practice.
\end{abstract}

Keywords: Conservation agriculture, Profitability, Productivity, Bangladesh

\section{Introduction}

Agriculture is the heart of Bangladesh economy where more than $80 \%$ farmers are smallholder having land less than 1.0 hectare. The rural economy constitutes a significant component of the national GDP with agriculture (including crops, livestock, fisheries and forestry) accounting for $17.2 \%$ (BBS, 2014). In order to feed the increasing population of Bangladesh, priority was given to produce more food through intensification of land usage (Akteruzzaman et al., 2012). Immediate objectives of more crop production have been achieved and crop production has increased by manifolds. For a shorter period, Bangladesh has attained self-sufficiency in food production but long term use of chemical fertilizer and pesticides in conjunction with monoculture of cereal crops without any organic fertilizer result in lack of organic matter content which causes a lot of problems to the soil health. As a result, soil fertility and productivity is decreasing day by day (Kafiluddin and Islam, 2008). In this context, introduction of conservation agriculture practice is becoming increasingly important in overcoming the problems of declining agricultural productivity in a developing country like Bangladesh.

Conservation agriculture practice is an approach to manage agro-ecosystems for improved and sustained productivity, increased profits and food security while preserving and enhancing the resource base and the environment. It can be defined as a concept for resource-saving agricultural crop production that strives to achieve acceptable profits together with high and sustained production levels while concurrently conserving the environment. FAO (2007) has determined three key principles in the process of conservation agriculture practice which are: a) continuous minimum mechanical soil disturbance; $b$ ) permanent organic soil cover; and c) diversified crop rotations. Also, community based movement on conservation agriculture practice may contribute to livelihoods and empowerment of communities (Rahman, 2001). Although this farming aims to help farmers to earn more income with reduced amount of labour, irrigation and other high energy external input costs; keep land healthy and productive; and conserve natural environment (Lampkin and Padel, 1994); about 8-10\% farmers around the world follow this practice (Parrott et al., 2006; Willer et al., 2008). 
In economic sense, conservation agriculture practice performs better than conventional farming. Savings on inputs may help to bring benefits forward by decreasing the cost of crop production. Cover crops may reduce the cost of labour, fertilizer and fuel for subsequent crops. It is possible that using a leguminous cover crop in one crop season can decrease the need for nitrogen fertilizer for the subsequent crop, cutting fertilizer costs over the span of just one season. Cover crops also have a positive effect on crop yield. Biculture (grass and legume) cover crops can increase crop yields by an average of $21 \%$ (Miguez and Bollero, 2005). Crop rotations, especially those involving three or more crops, have a positive effect on the yield of crop compared to traditional crop rotations (Boyle, 2006 and Duffy, 2012). A properly managed crop rotation is not associated with any yield decrease, rather it has the greatest potential to increase the yield.

Modalities of such farming have been described in a good number of literatures. A modest attempt has been made here to review the previous research studies which are: Nguema et al. (2013) conducted a research on farm-level economic impacts of conservation agriculture practice in Ecuador and found that specific cover crops, crop rotations and reduced tillage designed to reduce soil erosion and increase soil organic matter that can lead to increased incomes for farm households; Lai et al. (2012) conducted a comparative economic and gender, labor analysis of conservation agriculture practice in tribal villages within Kendujhar district of Odisha state, India and revealed that legume rotation without minimum tillage was more profitable than legume rotation with minimum tillage, which was comparatively more profitable than conventional agriculture; Mazvimavi et al. (2012) performed a productivity and efficiency analysis of maize under conservation agriculture practice in Zimbabwe and indicated that farmers produced $39 \%$ more output in conservation agriculture practice compared to conventional farming practice; Uddin et al. (2011) evaluated the status of organic farming in Bangladesh and declared that commercial organic farming has emerged as an alternate profitable farming enterprise for the growers; and Dhaliwal and Singh (2004) evaluated the socioeconomic impacts of zero-tillage technology on wheat for different locations in nine erstwhile districts of Punjab, India and observed a significant decline in the cost of production due to less use of farm machinery, labour, agro-chemicals and higher yield due to less lodging of crop.

The literature reviews mentioned indicate that most of the studies dealt with either crop profitability or productivity in conservation agriculture practice but these are not linked to the circumstance of Bangladesh. Therefore, to minimize the research gap, this study would be helpful at evaluating the impact of conservation agriculture practice on crop profitability and productivity in Bangladesh as compared to traditional agriculture, as well as examining the factors influencing adoption of this farming practice by the farming community in Bangladesh. The specific objectives of the study are: i) to examine the benefits of conservation agriculture practice on crop profitability and productivity in relation to conventional farming; and ii) to identify the determinants of adopting conservation agriculture practice by the farmers under different socioeconomic conditions.

\section{Materials and Methods}

The study was conducted in five agro-ecological zones of Bangladesh where the movement for practicing conservation agriculture are getting interest among farmers for several years. The considered districts were Mymensingh (major crop: potato), Bogra (major crop: bean), Tangail (major crop: pineapple), Sherpur (major crop: rice) and Jamalpur (major crop: wheat). Three categories of farmers namely, focal farmers (farmers receiving technical and logistic support for practicing conservation agriculture from the project and having regular contact with extension support staff), proximal farmers (neighboring of focal farmers receiving indirect support like technical advice and having occasional contact with the extension staff) and control farmers (who are receiving no training and technical support on conservation agriculture from any organization and also from the project staff) were targeted for investigation. In each locale of the study, a total of 60 farmers (10 focal, 20 proximal and 30 control) were selected; of which focal farmers were selected purposively, and proximal and control farmers were selected randomly. Thus, a total of 300 farmers were included as the sample for observation and data collection. Primary data were collected through questionnaire survey, focus group discussion (FGD) and key informant interview (KII) with local stakeholders. Secondary sources of data in the form of handouts, reports, publications, notifications, etc. having relevance with this study were also consulted. 


\section{Analytical techniques}

\section{Profitability analysis}

Profitability of crop farming from the view point of individual farmer was measured in terms of gross return, gross margin, net return and benefit cost ratio (undiscounted). The formula need for the calculation of profitability is discussed below:

\section{Gross return (GR)}

Gross return was calculated by multiplying the total volume of output of an enterprise by the average price in the harvesting period (Dillon and Hardaker, 1993). The following equation was used to estimate GR:

$$
\begin{aligned}
& G R=Y_{m} P_{m}+Y_{b} P_{b} \\
& \text { Where, } \\
& Y_{m}=\text { Yield of main product per unit area; } \\
& P_{m}=\text { Price of main product; } \\
& Y_{b}=\text { Yield of by-product per unit area; and } \\
& P_{b}=\text { Price of by-product. }
\end{aligned}
$$

\section{Gross margin (GM)}

Gross margin was calculated by the difference between gross return and total variable costs. That is,

$\mathrm{GM}=\mathrm{GR}-\mathrm{TVC}$

Where,

$\mathrm{GR}=$ Gross return; and

TVC $=$ Total variable cost.

\section{Net return (NR)}

Net return was calculated by deducting all costs (variable and fixed) from the gross return. To estimate the relative profitability of crops produced, profit equation of the following algebraic form was used:

$\mathrm{NR}=\mathrm{GR}-\mathrm{GC}$

Where,

$\mathrm{GR}=$ Gross return;

$\mathrm{GC}=$ Gross cost (i.e., TFC + TVC);

TFC $=$ Total fixed cost per unit area; and

TVC $=$ Total variable cost per unit area.

\section{Benefit cost ratio (BCR)}

A benefit cost ratio $(B C R)$ is a relative measure which is used to compare the return per unit of cost. BCR was estimated as a ratio of gross return and gross cost. The formula of calculating BCR (undiscounted) is shown as below:

$$
\begin{aligned}
& \mathrm{BCR}=\mathrm{GR} \div \mathrm{GC} \\
& \text { Where, } \\
& \mathrm{GR}=\text { Gross return; and } \\
& \mathrm{GC}=\text { Gross cost (i.e., TFC + TVC). }
\end{aligned}
$$

\section{The Enyedi's index of crop productivity measurement}

The Enyedi's index was used to measure the productivity of respective crops in the research areas compared to the entire regions (Ogale and Nagarale, 2014). For calculation, the following formula was used:

Crop productivity $=\left(\mathrm{YT}_{\mathrm{n}} \div \mathrm{Y}_{\mathrm{n}} \mathrm{T}\right) \times 100$

Where,

$Y=$ Production of the respective crop in the unit area;

$\mathrm{Y}_{\mathrm{n}}=$ Total production of the crop in the entire region;

$\mathrm{T}=$ Cultivated unit area under the respective crop; and

$\mathrm{T}_{\mathrm{n}}=$ Cultivated area in the entire region under the respective crop. 


\section{Logit model}

In order to investigate the extent of influence of the determinants on the decision making status of adopting conservation agriculture practice, logistic regression analysis (i.e., logit model) was used. In the present research, the following logit model was used to identify the level of influence of the factors influencing adoption of conservation agriculture practice by the farmers:

$Z_{i}=\ln \left[P_{i} \div\left(1-P_{i}\right)\right]=\beta_{0}+\beta_{1} Q_{1}+\beta_{2} Q_{2}+\beta_{3} Q_{3}+\beta_{4} Q_{4}+\beta_{5} Q_{5}+\beta_{6} Q_{6}+\beta_{7} Q_{7}+\beta_{8} Q_{8}+U_{i}$

Where,

$P_{i}$ is the probability of adoption and non-adoption of conservation agriculture practice, $P_{i}=1$ indicates adoption and $\mathrm{P}_{\mathrm{i}}=0$ indicates non-adoption.

Dependent variable:

$Z_{i}=$ Probability of adoption of conservation agriculture practice.

Independent variables:

$Q_{1}=$ Household size (no.);

$\mathrm{Q}_{2}=$ Educational level of household head (years of schooling);

$\mathrm{Q}_{3}=$ Age of household head (years);

$\mathrm{Q}_{4}=$ Farm size (ha);

$Q_{5}=$ Farm income (Tk.);

$Q_{6}=$ Non-farm income (Tk.);

$Q_{7}=$ Extension contact $\left(P_{i}=1\right.$ indicates having extension contact and

$P_{i}=0$ indicates having no extension contact);

$\mathrm{Q}_{8}=$ Farming experience (years of farming);

$\beta_{0}=$ Intercept;

$\beta_{1}$ to $\beta_{8}=$ Regression coefficients of the dependent variables; and

$\mathrm{U}_{\mathrm{i}}=$ Error term.

The marginal probabilities of the key determinants of adopting conservation agriculture practice by the farmers was estimated based on expressions derived from the marginal effect of the logit model was as follows:

$d Z / d Q=\beta_{i}\left\{P_{i}\left(1-P_{i}\right)\right\}$

Where,

$\beta_{\mathrm{i}}=$ Estimated logit regression coefficient with respect to the $\mathrm{i}^{\text {th }}$ factor; and

$P_{i}=$ Estimated probability of farmers' adoption status.

\section{Results and Discussion}

\section{Socioeconomic characteristics of the selected farmers}

Table 1 represents the basic information of the selected farmers in the study areas. It is found that average household and farm size of focal, proximal and control farmers was 6.0, 5.0 and 6.0; and 0.48, 0.41 and 0.52 , respectively. Average dependency ratio of focal farmers (1.5) was comparatively lower than proximal and control farmers (1.7 and 3.0, respectively) which indicated that focal farmers were more self-sufficient and self-employed. The percentages of male and female respondents were 68.0, 69.5 and 69.2; and 32.0, 30.5 and 30.8 for focal, proximal and control farmers, respectively. Average age of focal, proximal and control farmers was 32,37 and 36 years, respectively. Though 42.0 percent focal farmers could put sign only, majority of the proximal and control farmers (56.5 and 55.6 percent, respectively) were illiterate in the study areas.

Most of the farmers were engaged in agriculture as well as other income generating activities like labour selling, service, small business, etc. (76.0 percent for both focal and proximal farmers and 70.8 percent control farmers). It is also shown that majority of the farmers were commercial farmers $(82.0,70.5$ and 76.0 percent focal, proximal and control farmers, respectively) in the study areas (Table 1). 
Table 1. Basic information about the selected farmers

\begin{tabular}{llccc}
\hline \multirow{2}{*}{ Particulars } & & \multicolumn{3}{c}{ Farmers' categories } \\
\cline { 3 - 5 } Average household size (no.) & & Focal & \multicolumn{2}{c}{ Proximal } \\
Average farm size (ha) & & 6.0 & 5.0 & 6.0 \\
Average dependency ratio (no.) & Male & 0.48 & 0.41 & 0.52 \\
Average sex distribution & Female & 1.5 & 1.7 & 3.0 \\
(\% of farmers) & & 68.0 & 69.5 & 69.2 \\
Average age (years) & Illiterate & 32.0 & 30.5 & 30.8 \\
Literacy rate & Sign only & 32 & 37 & 36 \\
(\% of farmers) & Primary and above & 32.0 & 56.5 & 55.6 \\
Occupational status & Agriculture only & 42.0 & 27.5 & 22.4 \\
(\% of farmers) & Agriculture and others & 26.0 & 16.0 & 22.0 \\
Farming systems practiced & Subsistence & 24.0 & 24.0 & 29.2 \\
(\% of farmers) & Commercial & 76.0 & 76.0 & 70.8 \\
\hline
\end{tabular}

Source: Field survey, 2015-16.

\section{Profitability analysis of crop farming}

One of the most important aspects of this research was to evaluate the profitability of major crops (potato, bean, pineapple, rice and wheat) in the study areas. A limited amount of input support (i.e., seeds or planting materials, manures and fertilizers, organic pesticides, care and management, etc.) were provided to the focal farmers at free of cost for 10.0 decimal land (command area) for cultivating crops following the principles of conservation agriculture practice. Proximal farmers were not provided any kind of input support but they gathered experience observing the farming practice of focal farmers. On the other hand, control farmers neither received any input support nor technical advice for practicing such farming.

\section{Types of inputs used in crop production}

The types of inputs used in crop production by the farmers in the study areas are shown in Table 2. It is seen that focal farmers did not use any kind of synthetic fertilizer like urea, TSP, MP, etc. except a negligible amount of DAP. They were fully dependent on the use of organic fertilizers like cowdung, compost, vermicompost, etc. IPM technology was used by the focal farmers for pest management. No pesticide, herbicide or medicine was used by them during the crop production.

Table 2. Types of inputs used in crop production

\begin{tabular}{|c|c|c|c|c|}
\hline \multirow{2}{*}{ Inputs } & & \multicolumn{3}{|c|}{ Farmers' categories } \\
\hline & & Focal & Proximal & Control \\
\hline \multicolumn{5}{|c|}{ Synthetic } \\
\hline \multirow{6}{*}{ Fertilizers } & Urea & $x$ & $\sqrt{ }$ & $\sqrt{ }$ \\
\hline & TSP & $x$ & $\sqrt{ }$ & $\sqrt{ }$ \\
\hline & MP & $x$ & $x$ & $\sqrt{ }$ \\
\hline & DAP & $\S$ & $\sqrt{ }$ & $\sqrt{ }$ \\
\hline & Gypsum & $x$ & $x$ & $\sqrt{ }$ \\
\hline & Borax & $x$ & $x$ & $\sqrt{ }$ \\
\hline \multirow{2}{*}{\multicolumn{2}{|c|}{$\begin{array}{l}\text { Pesticides and herbicides } \\
\text { Medicine }\end{array}$}} & $x$ & $\S$ & $\sqrt{ }$ \\
\hline & & $x$ & $\S$ & $\sqrt{ }$ \\
\hline \multicolumn{5}{|c|}{ Organic } \\
\hline \multirow{5}{*}{ Fertilizers } & Cowdung & $\sqrt{ }$ & $\sqrt{ }$ & $\S$ \\
\hline & Compost & $\sqrt{ }$ & $\S$ & $\S$ \\
\hline & Vermicompost & $\sqrt{ }$ & $x$ & $x$ \\
\hline & Oil cake & $\sqrt{ }$ & $x$ & $x$ \\
\hline & Bioslurry & $\sqrt{ }$ & $x$ & $x$ \\
\hline \multicolumn{2}{|c|}{ IPM technology } & $\sqrt{ }$ & $x$ & $x$ \\
\hline
\end{tabular}

Source: Field survey, 2015-16.

Note: $\sqrt{ }, \S$ and $\times$ indicate full, partial and no use, respectively. 
Proximal farmers observed the input use pattern of focal farmers but they did not diminish full use of synthetic fertilizers. No use of MP, gypsum and borax was confirmed by them with full use of urea, TSP and DAP. In terms of organic fertilizers, they adopted full use of cowdung and partial use of compost with no use of vermicompost, oilcake and bioslurry. They used pesticide, herbicide and medicine partially in their crop production but did not use any sort of IPM technology. On the other hand, control farmers in the study areas continued full use of all kinds of synthetic fertilizers, pesticides, herbicides and medicine along with partial use of cowdung and compost as organic fertilizers. No IPM technology was used by the control farmers in the study areas (Table 2).

\section{Estimation of production cost}

For calculating total production cost, variable and fixed costs were taken into consideration. The components of variable cost were: i) human labour; ii) power tiller cost; iii) seeds/seedlings; iv) fertilizers; v) pesticides and herbicides; vi) medicine; vii) irrigation; and viii) fencing. Fixed cost items for crop production were as follows: i) lease value of land; and ii) interest on operating capital.

Table 3. Cost of crop production

(in Tk.)

\begin{tabular}{|c|c|c|c|c|c|c|c|c|}
\hline \multirow{3}{*}{ Cost items } & & & \multicolumn{6}{|c|}{ Farmers' categories } \\
\hline & & & \multicolumn{2}{|c|}{ Focal } & \multicolumn{2}{|c|}{ Proximal } & \multicolumn{2}{|c|}{ Control } \\
\hline & & & Before & After & Before & After & Before & After \\
\hline \multirow{2}{*}{\multicolumn{9}{|c|}{ Command area (10.0 decimal) }} \\
\hline \multirow{4}{*}{\multicolumn{3}{|c|}{$\begin{array}{l}\text { Variable costs } \\
\text { Human labour } \\
\text { Power tiller } \\
\text { Seed/seedlings }\end{array}$}} & & & & & & \\
\hline & & & 1577 & 1483 & 1558 & 1512 & 1575 & 1564 \\
\hline & & & 440 & 293 & 444 & 374 & 448 & 441 \\
\hline & & & 1380 & & 1383 & 1349 & 1395 & 1380 \\
\hline \multirow{12}{*}{ Fertilizers } & \multirow{6}{*}{ Synthetic } & Urea & 415 & . & 393 & 376 & 405 & 404 \\
\hline & & TSP & 382 & - & 393 & 356 & 385 & 376 \\
\hline & & MP & 270 & - & 267 & & 269 & 263 \\
\hline & & DAP & 105 & 74 & 104 & 88 & 104 & 103 \\
\hline & & Gypsum & 21 & - & 22 & - & 21 & 20 \\
\hline & & Borax & - & - & - & 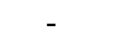 & 10 & 10 \\
\hline & \multirow{5}{*}{ Organic } & Cowdung & 80 & 163 & 84 & 94 & 81 & 83 \\
\hline & & Compost & - & 25 & - & 24 & - & 15 \\
\hline & & Vermicompost & - & 12 & - & - & - & - \\
\hline & & Oil cake & - & 44 & - & - & - & - \\
\hline & & Bioslurry & - & 92 & - & - & - & - \\
\hline & \multicolumn{2}{|l|}{ Total } & 1273 & 410 & 1263 & 938 & 1275 & 1274 \\
\hline Pesticides & \multirow{2}{*}{\multicolumn{2}{|c|}{$\begin{array}{l}\text { Synthetic } \\
\text { IPM technology }\end{array}$}} & 113 & 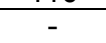 & 114 & 100 & 110 & 108 \\
\hline and & & & mo & 26 & - & & 等 & . \\
\hline herbicides & \multicolumn{2}{|c|}{ Total } & 113 & 26 & 114 & 100 & 110 & 108 \\
\hline \multirow{2}{*}{\multicolumn{3}{|c|}{$\begin{array}{l}\text { Medicine } \\
\text { Irrigation }\end{array}$}} & 16 & & 20 & 9 & 19 & 18 \\
\hline & & & 350 & 350 & 351 & 351 & 350 & 350 \\
\hline \multicolumn{3}{|c|}{ Fencing } & 400 & 400 & 405 & 401 & 405 & 404 \\
\hline \multicolumn{3}{|c|}{ Total variable cost (TVC) } & 5549 & 4335 & 5538 & 5034 & 5577 & 5539 \\
\hline \multirow{2}{*}{\multicolumn{3}{|c|}{$\begin{array}{l}\text { Change in TVC (\%) } \\
\text { Fixed costs }\end{array}$}} & \multicolumn{2}{|c|}{-21.9} & \multirow{2}{*}{\multicolumn{2}{|c|}{-9.1}} & \multirow{2}{*}{\multicolumn{2}{|c|}{-0.7}} \\
\hline \multirow{2}{*}{\multicolumn{3}{|c|}{ Lease value of land }} & 283 & 372 & & & & \\
\hline \multirow{2}{*}{\multicolumn{3}{|c|}{$\begin{array}{l}\text { Interest on operating capital } \\
\text { Total fixed cost (TFC) }\end{array}$}} & 488 & 347 & 488 & 374 & $\begin{array}{l}283 \\
488\end{array}$ & $\begin{array}{l}372 \\
396\end{array}$ \\
\hline & & & 771 & 719 & 771 & 746 & 771 & 768 \\
\hline \multirow{3}{*}{\multicolumn{3}{|c|}{$\begin{array}{l}\text { Change in TFC }(\%) \\
\text { Total cost (TC }=\text { TVC + TFC) } \\
\text { Change in TC }(\%)\end{array}$}} & \multicolumn{2}{|c|}{-6.7} & \multicolumn{2}{|c|}{-3.2} & & \\
\hline & & & 6320 & 5054 & 6309 & 5780 & 6348 & 6307 \\
\hline & & & & & & & & \\
\hline & & & Farm size & $47 \mathrm{ha})$ & & & & \\
\hline Total variab & cost (TVC) & & 64418 & 50325 & 64291 & 58440 & 64743 & 64302 \\
\hline Change in & $\mathrm{C}(\%)$ & & & & & & & \\
\hline Total fixed & st (TFC) & & 8951 & 8347 & 8951 & 8660 & 8951 & 8916 \\
\hline Change in & $C(\%)$ & & & & & & & \\
\hline $\begin{array}{l}\text { Total cost } \\
\text { Change in }\end{array}$ & $\begin{array}{l}=\text { TV́C }+\mathrm{T} \\
(\%)\end{array}$ & & 73369 & 58672 & 73242 & 67100 & 73694 & $6^{73218}$ \\
\hline
\end{tabular}

Source: Authors' estimation based on field survey, 2015-16. 
Table 3 shows the cost of employing inputs in crop production in the command area where farmers were given input support to adopt conservation agriculture practice. It is evident that before adopting conservation agriculture, total variable cost of focal, proximal and control farmers was Tk. 5549, Tk. 5538 and Tk. 5577 per 10.0 decimal, respectively; whereas it became Tk. 4335, Tk. 5034 and Tk. 5539, respectively after adopting conservation agriculture. Total variable cost of focal, proximal and control farmers was decreased by $21.9,9.1$ and 0.7 percent, respectively after adopting conservation agriculture practice. Total fixed cost was decreased to Tk. 719, Tk. 746 and Tk. 768 in case of focal, proximal and control farmers, respectively from Tk. 771 after adopting conservation agriculture. Total fixed cost of focal, proximal and control farmers was decreased by $6.7,3.2$ and 0.2 percent, respectively. Total cost of focal, proximal and control farmers was Tk. 6320, Tk. 6309 and Tk. 6348 per 10.0 decimal, respectively before adopting conservation agriculture while it was reduced to Tk. 5054, Tk. 5780 and Tk. 6307, respectively after adopting conservation agriculture practice. Total cost of focal, proximal and control farmers was reduced by $20.0,8.4$ and 0.6 percent, respectively after adopting conservation agriculture practice (Table 3).

The cost of crop production in the command area was converted into per 0.47 ha land (average farm size of all the three categories of farmers) to check the cost that might be incurred if they would follow conservation agriculture practice to their entire cropped area. It is seen from Table 3 that in case of focal, proximal and control farmers, total variable cost after adopting conservation agriculture practice would be declined to Tk. 50325, Tk. 58440 and Tk. 64302 per 0.47 ha, respectively which would be Tk. 64418, Tk. 64291 and Tk. 64743, respectively before practicing conservation agriculture. Total fixed cost in terms of focal, proximal and control farmers would be reduced to Tk. 8347, Tk. 8660 and Tk. 8916, respectively from Tk. 8951 after adopting conservation agriculture. Total cost of focal, proximal and control farmers would be Tk. 73369 , Tk. 73242 and Tk. 73694 per 0.47 ha, respectively before adopting conservation agriculture which would be dropped to Tk. 58672, Tk. 67100 and Tk. 73218, respectively after practicing conservation agriculture. The percentages of change in total variable cost, total fixed cost and total cost in case of 0.47 ha land would be identical to those of the command area.

\section{Estimation of return from production}

It is apparent from Table 4 that gross return of focal, proximal and control farmers before adopting conservation agriculture was Tk. 13107, Tk. 12174 and Tk. 12454 per 10.0 decimal, respectively; and it was increased to Tk. 12970 and Tk. 13736 in case of proximal and control farmers, respectively but decreased to Tk. 13031 in case of focal farmers after adopting conservation agriculture practice. Gross return increased by 6.5 and 10.3 percent in case of proximal and control farmers, respectively but declined by 0.6 percent in case of focal farmers after adopting conservation agriculture. Gross margin of focal, proximal and control farmers were increased by 15.1, 19.6 and 19.2 percent, respectively after adopting conservation agriculture. Net return before adopting conservation agriculture was Tk. 6787, Tk. 5865 and Tk. 6106 per 10.0 decimal in terms of focal, proximal and control farmers, respectively which was increased to Tk. 7977, Tk. 7190 and Tk. 7429 per 10.0 decimal, respectively after adopting conservation agriculture. Net return of focal, proximal and control farmers were increased by 17.5, 22.6 and 21.7 percent, respectively after adopting conservation agriculture. BCR of focal, proximal and control farmers was increased to $2.58,2.24$ and 2.18 , respectively from $2.07,1.93$ and 1.96 , respectively after practicing conservation agriculture indicating an increase in BCR of the farmers by $24.3,16.3$ and 11.0 percent, respectively after adopting conservation agriculture practice.

The profitability analysis of crop produced in the command area was converted into per 0.47 ha land (average farm size of all the three categories of farmers) to check whether the intervention would be beneficial to the farmers if they would practice conservation agriculture for their entire farm size. It is evident from Table 4 that gross margin of focal, proximal and control farmers would be increased to Tk. 100952, Tk. 92129 and Tk. 95159 from Tk. 87741, Tk. 77037 and Tk. 79835; and net return would be increased to Tk. 92605, Tk. 83469 and Tk. 86243 from Tk. 78790 , Tk. 68087 and Tk. 70885, respectively

after adopting conservation agriculture practice. BCR of focal, proximal and control farmers before and after adopting conservation agriculture situation would remain the same for the command area. Also, the 
percentages of change in gross return, gross margin, net return and BCR of the farmers in the study areas would be identical to those of the command area. This findings is slightly similar with the result of Dhaliwal and Singh (2004) where the authors observed a significant decline in the cost of crop production due to less use of farm machinery, labour and agro-chemicals; and higher yield due to less lodging of crop because of following zero-tillage technology.

Table 4. Average return from crop production

\begin{tabular}{|c|c|c|c|c|c|c|c|}
\hline \multirow{3}{*}{ Return items } & & \multicolumn{6}{|c|}{ Farmers' categories } \\
\hline & & \multicolumn{2}{|c|}{ Focal } & \multicolumn{2}{|c|}{ Proximal } & \multicolumn{2}{|c|}{ Control } \\
\hline & & Before & After & Before & After & Before & After \\
\hline \multicolumn{8}{|c|}{ Command area (10.0 decimal) } \\
\hline & Quantity (quintal) & 4.5 & 4.3 & 4.1 & 4.3 & 4.1 & 4.5 \\
\hline \multirow[t]{2}{*}{ Main product } & Price (Tk./quintal) & 2250 & 2375 & 2300 & 2350 & 2300 & 2375 \\
\hline & Total (Tk.) & 10125 & 10213 & 9430 & 10105 & 9430 & 10688 \\
\hline \multirow{3}{*}{ By- product } & Quantity (quintal) & - & - & - & - & - & - \\
\hline & Price (Tk./ quintal) & - & - & - & - & - & - \\
\hline & Total (Tk.) & 115 & 130 & 129 & 132 & 131 & 132 \\
\hline \multirow{3}{*}{ Relay product } & Quantity (quintal) & - & - & - & - & - & - \\
\hline & Price (Tk./ quintal) & - & - & - & - & - & - \\
\hline & Total (Tk.) & 2867 & 2688 & 2615 & 2733 & 2893 & 2916 \\
\hline \multirow{2}{*}{\multicolumn{2}{|c|}{$\begin{array}{l}\text { Gross return (GR) (Tk.) } \\
\text { Change in GR }(\%)\end{array}$}} & 13107 & 13031 & 12174 & 12970 & 12454 & 13736 \\
\hline & Change in GR (\%) & \multicolumn{2}{|c|}{-0.6} & \multicolumn{2}{|c|}{6.5} & \multicolumn{2}{|c|}{10.3} \\
\hline \multirow{2}{*}{\multicolumn{2}{|c|}{$\begin{array}{l}\text { Gross margin }(\mathrm{GM}=\mathrm{GR} \\
\text { Change in } \mathrm{GM}(\%)\end{array}$}} & 7558 & 8696 & 6636 & 7936 & 6877 & 8197 \\
\hline & & \multicolumn{2}{|c|}{15.1} & \multicolumn{2}{|c|}{19.6} & \multicolumn{2}{|c|}{19.2} \\
\hline \multicolumn{2}{|c|}{ Net return (NR = GF } & 6787 & 7977 & 5865 & 7190 & 6106 & 7429 \\
\hline Change in NR & & \multicolumn{2}{|c|}{17.5} & \multicolumn{2}{|c|}{22.6} & \multicolumn{2}{|c|}{21.7} \\
\hline \multirow{2}{*}{\multicolumn{2}{|c|}{$\begin{array}{l}\text { Benefit cost ratio }(B C R=G R \div T C) \\
\text { Change in } B C R(\%)\end{array}$}} & 2.07 & 2.58 & 1.93 & 2.24 & 1.96 & 2.18 \\
\hline & & \multicolumn{2}{|c|}{24.3} & \multicolumn{2}{|c|}{16.3} & \multicolumn{2}{|c|}{11.0} \\
\hline \multicolumn{8}{|c|}{ Farm size (0.47 ha) } \\
\hline \multicolumn{2}{|c|}{ Gross return (GR) (Tk.) } & 152159 & 151277 & 141328 & 150569 & 144578 & 159461 \\
\hline Change in GR & & \multicolumn{2}{|c|}{-0.6} & \multicolumn{2}{|c|}{6.5} & & \\
\hline Gross margin ( & 1 = GR - TVC) (Tk.) & 87741 & 100952 & 77037 & 92129 & 79835 & 95159 \\
\hline Change in GM & & & & & & & \\
\hline Net return (NR & SR - TC) (Tk.) & 78790 & 92605 & 68087 & 83469 & 70885 & 86243 \\
\hline Change in NR & & & & & & & \\
\hline Benefit cost rat & $\mathrm{BCR}=\mathrm{GR} \div \mathrm{TC})$ & 2.07 & 2.58 & 1.93 & 2.24 & 1.96 & 2.18 \\
\hline Change in $\mathrm{BCF}$ & & & & & & & \\
\hline
\end{tabular}

Source: Authors' estimation based on field survey, 2015-16.

\section{Measurement of crop productivity}

Using the Enyedi's crop productivity index, the crop productivity in the study areas was estimated in comparison with the crop production in the entire region which is represented by Table 6 . It is seen that per hectare crop production in case of focal, proximal and control farmers was 141.5, 140.3 and 140.3 quintal, respectively before adopting conservation agriculture which was increased to $142.2,141.8$ and 142.2 quintal per hectare, respectively after practicing conservation agriculture. Before adopting conservation agriculture practice, total cultivated area in the entire region was 4856 ha and after adopting conservation agriculture practice it was 4862 ha. Total crop production in the entire region was amplified to 1035548.4 quintal from 1034825.4 quintal after adopting conservation agriculture.

If the farmers would produce crop following all the principles of conservation agriculture in 0.47 ha (average farm size of all the three categories of farmers), the crop productivity of focal, proximal and control farmers would increase from 141.3, 140.1 and 140.1 percent, respectively to $142.1,141.7$ and 142.1 percent, respectively with respect to the entire region. Crop productivity was expected to increase in the next years of crop production, if practicing conservation agriculture would be continued. The result is slightly similar to Davis et al. (2012) where the researchers found that farmers experienced some moderately reduced yields in the first few years of retaining crop residue but after having properly managed systems, yields were regained by the next years. 
Table 6. Enyedi's crop productivity index

(in average)

\begin{tabular}{|c|c|c|c|c|c|c|}
\hline \multirow{3}{*}{ Particulars } & \multicolumn{6}{|c|}{ Farmers' categories } \\
\hline & \multicolumn{2}{|c|}{ Focal } & \multicolumn{2}{|c|}{ Proximal } & \multicolumn{2}{|c|}{ Control } \\
\hline & Before & After & Before & After & Before & After \\
\hline Production (quintal/ha) & 141.5 & 142.2 & 140.3 & 141.8 & 140.3 & 142.2 \\
\hline $\begin{array}{l}\text { Total production in the entire } \\
\text { region (quintal) }\end{array}$ & 1034825.4 & 1035548.4 & 1034825.4 & 1035548.4 & 1034825.4 & 1035548.4 \\
\hline Cultivated area (ha) & 0.47 & 0.47 & 0.47 & 0.47 & 0.47 & 0.47 \\
\hline $\begin{array}{l}\text { Total cultivated area in the } \\
\text { entire region (ha) }\end{array}$ & 4856 & 4862 & 4856 & 4862 & 4856 & 4862 \\
\hline $\begin{array}{l}\text { Crop productivity (\%) } \\
\text { Change in crop productivity (\%) }\end{array}$ & \multicolumn{2}{|c|}{0.5} & \multicolumn{2}{|c|}{1.1} & \multicolumn{2}{|c|}{1.4} \\
\hline
\end{tabular}

Source: Authors' estimation based on field survey, 2015-16.

\section{Determinants of adopting conservation agriculture practice}

A logit model had been used bringing about the factors influencing adoption of conservation agriculture practice by the farmers in the study areas. Eight independent variables were identified as major determinants of adopting conservation agriculture by the farmers in this study. Five out of eight independent variables included in the model were found significant in explaining the variation in adopting conservation agriculture practice by the farmers. These variables were educational level of household head, farm size, farm income, extension contact and farming experience of the farmers in the study areas (Table 7).

Therefore the estimated equation was as follows:

$$
Z_{i}=2.178+0.005 Q_{1}+1.131 Q_{2}-1.137 Q_{3}+1.127 Q_{4}+1.129 Q_{5}-0.022 Q_{6}+0.087 Q_{7}+0.023 Q_{8}
$$

Table 7. Estimates of logistic regression of determinants adopting conservation agriculture practice

\begin{tabular}{lcccccc}
\hline Variables & $\begin{array}{c}\text { Coefficient } \\
(\beta)\end{array}$ & $\begin{array}{c}\text { Standard } \\
\text { Error }\end{array}$ & $\mathrm{z}$ & $\mathrm{P}>|\mathrm{z}|$ & \multicolumn{2}{c}{$\begin{array}{c}\text { 95\% confidence } \\
\text { interval }\end{array}$} \\
\hline Constant & 2.178 & 1.588 & 1.37 & 0.170 & -0.936 & 5.291 \\
Household size $\left(\mathrm{Q}_{1}\right)$ & 0.005 & 0.002 & 2.70 & 0.079 & -0.009 & -0.001 \\
Educational level of household & 1.131 & 0.435 & 2.60 & $0.031^{* *}$ & -1.984 & -0.278 \\
head $\left(\mathrm{Q}_{2}\right)$ & -1.137 & 0.436 & -2.61 & 0.009 & 0.023 & 1.992 \\
Age of household head $\left(\mathrm{Q}_{3}\right)$ & 1.127 & 0.435 & 2.59 & $0.083^{*}$ & 0.273 & 1.980 \\
Farm size $\left(\mathrm{Q}_{4}\right)$ & 1.129 & 0.435 & 2.59 & $0.070^{*}$ & 0.275 & 1.982 \\
Farm income $\left(\mathrm{Q}_{5}\right)$ & -0.022 & 0.021 & -1.06 & 0.291 & -0.062 & 0.019 \\
Non-farm income $\left(\mathrm{Q}_{6}\right)$ & 0.087 & 0.100 & 0.87 & $0.004^{* * *}$ & -0.109 & 0.284 \\
Extension contact $\left(\mathrm{Q}_{7}\right)$ & 0.023 & 0.072 & 0.32 & $0.086^{*}$ & -0.119 & 0.164 \\
Farming experience $\left(\mathrm{Q}_{8}\right)$ & & & & & &
\end{tabular}

Source: Authors' estimation, 2015-16.

Note: ${ }^{* * *}{ }^{* \star}$ and ${ }^{*}$ indicate significant at $1 \%, 5 \%$ and $10 \%$ probability level, respectively.

Marginal effect was computed differently for discrete (i.e., categorical) and continuous variables. Marginal effect measured discrete change i.e., how predicted probabilities were changed as the binary independent variable changed from 0 to 1 . Marginal effects for continuous variables measured the instantaneous rate of change (Table 8 ).

\section{Household size}

The result of marginal effect shows that household size had a positive value of $d Z / d Q$ and it was 0.001 . It indicated that if household size increases by 1 unit, the probability of adopting conservation agriculture practice will increase by 0.001 times. 


\section{Educational level of household head}

Educational level of household head had a positive value of $d Z / d Q$ which was 0.281 and it was statistically significant at $5 \%$ probability level. It meant that if educational level of household head increases by 1 unit, the probability of adopting conservation agriculture practice will increase by 0.281 times. The reason was that farmers could gain better knowledge about conservation agriculture practice which could insist them to adopt this practice.

Table 8. Estimates of marginal effect of determinants adopting conservation agriculture practice

\begin{tabular}{lccccccc}
\hline Variables & $\mathrm{d} Z / \mathrm{dQ}$ & $\begin{array}{c}\text { Standard } \\
\text { Error }\end{array}$ & $\mathrm{z}$ & $\mathrm{P}>|\mathrm{z}|$ & $\begin{array}{c}95 \% \text { confidence } \\
\text { interval }\end{array}$ & $\mathrm{Q}$ \\
\hline Household size $\left(\mathrm{Q}_{1}\right)$ & 0.001 & 0.001 & 2.69 & 0.007 & -0.002 & -0.000 & 395.168 \\
Educational level of household & 0.281 & 0.108 & 2.61 & $0.039^{* *}$ & -0.492 & -0.070 & 737.084 \\
head $\left(\mathrm{Q}_{2}\right)$ & -0.283 & 0.108 & -2.62 & 0.009 & 0.071 & 0.494 & 286.907 \\
Age of household head $\left(\mathrm{Q}_{3}\right)$ & 0.280 & 0.108 & 2.60 & $0.092^{*}$ & 0.069 & 0.491 & 239.393 \\
Farm size $\left(\mathrm{Q}_{4}\right)$ & 0.280 & 0.108 & 2.60 & $0.061^{*}$ & 0.069 & 0.492 & 210.776 \\
Farm income $\left(\mathrm{Q}_{5}\right)$ & -0.005 & 0.005 & -1.06 & 0.291 & -0.015 & 0.005 & 38.346 \\
Non-farm income $\left(\mathrm{Q}_{6}\right)$ & 0.023 & 0.025 & 0.87 & $0.005^{* * *}$ & -0.027 & 0.070 & 5.804 \\
Extension contact $\left(\mathrm{Q}_{7}\right)$ & 0.006 & 0.018 & 0.32 & $0.053^{*}$ & -0.029 & 0.041 & 3.290 \\
Farming experience $\left(\mathrm{Q}_{8}\right)$ & & & & & & &
\end{tabular}

Source: Authors' estimation, 2015-16.

Note: ${ }^{* * *},{ }^{* *}$ and ${ }^{*}$ indicate significant at $1 \%, 5 \%$ and $10 \%$ probability level, respectively.

\section{Age of household head}

The result of marginal effect shows that age of household head had a negative value of $d Z / d Q$ and it was 0.283 . It implied that if age of household head increases by 1 unit, the probability of adopting conservation agriculture practice will decrease by 0.283 times.

\section{Farm size}

The result of marginal effect shows that farm size had a positive value of $d Z / d Q$ and it was 0.280 , which was statistically significant at $10 \%$ level of probability. It indicated that if farm size increases by 1 unit, the probability of adopting conservation agriculture practice will increase by 0.280 times. The reason was that with a large farm size, farmers became eager to apply new cropping technology in a noticeable amount of cropland keeping practicing conventional cropping technology in other cropland.

\section{Farm income}

Farm income had a positive value of $d Z$ / $d Q$ which was 0.280 and it was statistically significant at $10 \%$ level of probability. It demonstrated that if farm income increases by 1 unit, the probability of adopting conservation agriculture practice will increase by 0.280 times. The reason was that farmers intended to adopt new crop farming practice with an expectation of more money income from crop farming.

\section{Non-farm income}

Non-farm income had a negative value of $d Z / d Q$ and it was 0.005 . It implied that if non-farm income increases by 1 unit, the probability of adopting conservation agriculture practice will decrease by 0.005 times.

\section{Extension contact}

The result of marginal effect shows that extension contact had a positive value of $d Z / d Q$ and it was 0.023 , which was statistically significant at $1 \%$ level of probability. It implied that the probability of adopting conservation agriculture practice for those farmers who have extension contact is 0.023 times higher compared to those farmers who do not have extension contact. The reason was that farmers got influenced and motivated by the extension agents to adopt this farming practice. 


\section{Farming experience}

The result of marginal effect shows that farming experience had a positive value of $d Z$ / $d Q$ which was 0.006 , and it was statistically significant at $10 \%$ probability level. It demonstrated that if extension contact increases by 1 unit, the probability of adopting conservation agriculture practice will increase by 0.006 times. The reason was that farmers having existing knowledge and training on this farming practice were aware about its pros and cons which provoked them to adopt this farming practice.

\section{Conclusion and Recommendation}

The study concludes that conservation agriculture as a new resource saving farming practice was appreciated and successfully adopted by the farmers in the study areas. Farmers were provided limited input support for 10.0 decimal land (command area) to adopt conservation agriculture. The study reveals that with this limited support, farmers experienced a great reduction in their cost of production as well as a remarkable increase in the crop production in that command area. It is also evident from the study that if the farmers in the study areas would cultivate crop in their entire cropland according to this farming practice, it would be profitable compared to conventional farming practice. Though lower profit was experienced in the first cropping season, it was expected that profit will be higher within next two or three season. The study further reveals that crop productivity of the farmers adopting conservation agriculture practice increased in response to the crop production in the entire region. It is also seen from the study that five out of eight independent variables had significant influence on adoption of conservation agriculture practice by the farmers found from the logit model which were: educational level of household head, farm size, farm income, extension contact and farming experience of the farmers. Considering the findings of the study, some essential policy recommendations have been arisen which are: input support, motivation and extension services of government should be properly implemented to raise the awareness about practicing conservation agriculture and its importance on crop production. Therefore, it can be concluded that there is a great scope to improve the overall economic condition of farmers through adopting conservation agriculture practice.

\section{Acknowledgement}

The authors express gratefulness to the Ministry of Education (MoE) for funding to conduct this research.

\section{References}

Akteruzzaman, M., Jahan, H. and Haque, M.D. 2012. Practices of conservation agricultural technologies in diverse cropping systems in Bangladesh. Bangladesh J. Agric. Econs., 35(1-2): 143-144.

BBS, 2014. Statistical Yearbook of Bangladesh, Bangladesh Bureau of Statistics, Statistics Division, Ministry of Planning, Government of the People's Republic of Bangladesh, Dhaka.

Boyle, K. 2006. The economics of on-site conservation tillage, http://tinyurl.com/n3n8a3k (Last consulted: December 01, 2015).

Dhaliwal, H.S. and Singh, J. 2004. Socio-economic impact of zero-tillage technology in wheat in Punjab. Centre for Advancement of Sustainable Agriculture, National Agriculture Science Centre, New Delhi, India.

Dillon, J.L. and Hardaker, J.B. 1993. Farm management research for small farmer development, FAO, Rome.

Duffy, M. 2012. Conservation practices for landlords, http://www.extension.iastate.edu/agdm/crops/ html/ a1-41.html (Last consulted: December 01, 2015).

FAO, 2007. Food and Agriculture Organization of the United Nations.

Kafiluddin, A. and Islam, M.S. 2008. Fertilizer distribution, subsidy, marketing, promotion and agronomic use efficiency scenario in Bangladesh. Presented at IFA Crossroads Asia-Pacific 2008, Melbourne, Australia.

Lai, C. Chan, C., Halbrendt, J., Shariq, L., Roul, P., Idol, T., Ray, C. and Evensen, C. 2012. Comparative economic and gender, labor analysis of conservation agriculture practices in tribal villages in India. International Food and Agribusiness Management Review, 15(1): 73-86.

Lampkin, N.H. and Padel, S. 1994. The economics of organic farming. An international perspective. Cab International, Oxon, U.K. 
Mazvimavi, K., Ndlovu, P.V., Henry, A. and Murendo, C. 2012. Productivity and efficiency analysis of maize under conservation agriculture in Zimbabwe. Presented at International Association of Agricultural Economists Conference, Foz do Iguaçu, Brazil.

Miguez, F.E. and Bollero, G.A. 2005. Review of corn yield response under winter cover cropping systems using meta-analytic methods. Crop Science, 45(6): 2318.

Nguema, A., Norton, G.W., Alwang, J., Taylor, D.B., Barrera, V. and Bertelsen, M. 2013. Farm-level economic impacts of conservation agriculture in Ecuador. Experimental Agriculture, 49(1): 134-147.

Ogale, S. and Nagarale, V. 2014. Agricultural productivity of the Baramati Tahsil, Pune district. IOSR- JAVS, 7(5): 25-30.

Parrott, N., Olesen, J.E. and Hogh-Jensen, H. 2006. Certified and non-certified organic farming in the developing world. Global development of organic agriculture: Challenges and prospects. CAB International, Wallingford, Oxon.

Rahman, M.H. 2001. The influence of extension on the introduction of organic farming in Bangladesh. Litverlag Münster, Hamburg, Germany.

Uddin, M.N., Ahmed, S. and Halim, G.M.A. 2011. Status of organic farming in Bangladesh. Country paper submitted to regional workshop on "ANSOFT" of AFACI PAN-ASIAN Project, RDA, Suwon, Korea.

Willer, H., Yussefi, M., Menzler and Sorensen, N. 2008. The world of organic agriculture statistics and emerging trends 2008 , main results. The World of Organic Agriculture, Bonn. 